\title{
Creating Batik Motifs from Minangkabau Manuscript Illumination
}

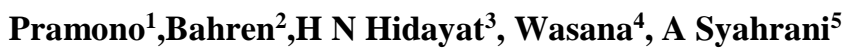 \\ $\left\{{ }^{1}\right.$ pramono@hum.unand.ac.id, ${ }^{2}$ bahren@hum.unand.ac.id, ${ }^{3}$ herrynh@ $@$ hum.unand.ac.id, ${ }^{4}$ wasana@hum.una \\ nd.ac.id, ${ }^{5}$ agussyahrani@fkip.untan.ac.id\} \\ 1,2,3,4 Universitas Andalas Padang, Indonesia \\ ${ }^{5}$ Universitas Tanjung Pura Pontianak, Indonesia
}

\begin{abstract}
Until now, efforts to apply manuscripts as one of the past products are very limited. Manuscripts conservation and preservation still focus on physical rescue. Meanwhile, illuminations in a manuscript by some philologists themselves are still considered as mere decoration of manuscript. In fact, as one of the products of culture, illumination is a symbol of civilization. This paper explains the effort to create batik motifs from the Minangkabau manuscript illumination. During this research, the illumination was chosen from the Minangkabau manuscript which was considered unique and had certain characteristics. This article presents a transformation of the manuscript illumination found at Surau Mato Aie which is considered as the longest manuscript in West Sumatra. Through the steps of selection, layout, and design, the illumination then transformed into a batik motif. As a result, the batik motif can be applied as an effort to develop a creative industry based on local knowledge.
\end{abstract}

Keywords: Batik, Motifs, Design, Manuscript, Illumination

\section{INTRODUCTION}

Until now, philology is a field that is less desirable in Indonesia. Besides caused by objects from the past, the step of philological research has a high difficulty and requires great accuracy. Kurniawan[1]stated that the philology research step must go through several stages, including transliteration and editing. This philology research is very difficult because a researcher has to compile a stemma codicum and have broad abilities in the field of culture, diachronic grammar, literature, or maybe even social and political history. Therefore, until this decade the Indonesian philology did not seem to develop slowly and not reaching significant progress.

On the other hand, the manuscript as a philological research material object has a lot of potential as an object of research in fields other than philology. However, of course, in practice, it still requires philology as the basis for its development, both theoretical and practical[2].

Mu'jizah [3]stated that the world appreciation for Indonesian manuscripts has at a high level. One performance which is classified as a world-class performance is I La Galigo directed by Robert Wilson. The performance was held in several cities, such as Rotterdam (Netherlands), Barcelona (Spain), New York (United States), Melbourne (Australia), 
Singapore, Jakarta, and Makassar. Basically, this kind of creations is also held in Yogyakarta at Prambanan Temple which is the Ramayana Story ballet.

Besides manuscript content or text, commonly called intrinsic aspect in literature, illumination is an element that can be researched. In addition to scientific aspects, illumination can be used in practical aspects. According to Safari[4], illumination is an art that beautifies an object rather than clarifying or explaining the contents of a text. Illumination is important because illumination is one of the aesthetic media and midpoints of explanation for the text. According to Gallop and Arps[5]illumination in Indonesian corresponds to the term sungging art, and in Yogyakarta it is called the renggan wadana. Luqman [6]make an introduction to the typical culture of the archipelago developed in the form of Javanese manuscript illumination motifs as a form of efforts to preserve the culture of the archipelago, as well as the role of the museum for appreciative learning which is very good in learning.

Mulyadi [7]states that the decorations in the manuscript are classified into two, the frame decoration which is usually found on early and last page and decoration that supports the text. Based on this, the decoration in the manuscript can be classified into decoration or images that are not related to text, namely illumination, and decoration that are related or even support the contents of the text, which is called illustration. Because of its aesthetic functions, manuscript illumination can be referred to as decoration.

According to the visual form, the decoration is divided into patterns and motifs. The pattern is the spread of shapes and colors in a particular loop, while the motif is the basic theme of an ornamental variety. In the traditional variety, there are various forms of patterns and motifs. The Minangkabau ornamental variety especially displays animal and plant motifs. Like other traditional decorative motifs, this Minangkabau decorative motif combines symmetrical and asymmetrical patterns. The absorption of motifs from natural elements is one of the characteristics of traditional motifs including Minangkabau decorative motifs. "Kaluak $P a k u "$ is taken from ferns, "itiak pulang patang" is taken from ducks that march home in the afternoon [8].

As one of the alternative development of philology, manuscripts can be used as creative objects. Media transformation is one of them. Stories or content of life values in the text can be transformed into a readable object, as a continuation of editing[9]-[11]. In addition, illumination can be developed into motif designs for various purposes. Motif designs based on illumination can be developed into batik motif designs. This effort began to be carried out both by philologists and batik industry practitioners. Batik is a traditional textile art of Indonesia, in which through its appearance we may excerpt the customs, traditional values, way of life, spiritual meanings, and cultural characteristics of Indonesian people[12].

Rudiyanto [13] succeeded in developing batik motifs from the illumination of the Mato Aie Pakandangan Khutbah Manuscript in West Sumatra. Dewi[14]designed a batik motif from Madura manuscripts and produced it. Nurhayati [15]conducted the design and modification of batik motifs from the manuscript illumination of the Mangkunegaran Temple in Surakarta. Pramono added[16], the development of batik motifs from manuscript illuminations could also help develop religious tourism locations in West Sumatra.Minangkabau ornamental or decorative arts are generally based on ornaments or pictures on the carvings of the rumah gadang and songket. According to Marah[17], talking about decoration in Minangkabau means talking about life and carving development.

Generally, decorative motifs in Minangkabau come from carved motifs found in rumah gadang. Carving on traditional houses is a source of developments in carving motifs public known today. From the name, the Minangkabau decorative motifs are based on three main things, (1) motifs derived from the plant, such as "aka badaun" 'leafy root' and "bungo 
mantimun" 'cucumber flower'; (2) motifs from the animal, such as "itiak pulang patang", "ducks that march home in the afternoon" and "kijang balari" 'running antelope'; and (3) motifs of everyday objects, such as "carano kanso" 'copper pan' and "jalo taserak" 'spread net'. This Minangkabau carving art, presumably, was born related to a belief that developed in the community at that time; born with the spiritual messages delivered in the form of carvings or decorative items, which showed the Islamic influence.

\section{RESEARCH METHOD}

This paper describes the transformation of illumination into batik motifs as one form of philological development, both theoretical and practical. In this case, the manuscript that became the object of discussion was the Minangkabau manuscript. Materials object of this transformation is illumination on Surau Mato Aie manuscript. Because of the length of the manuscript, illumination was chosen from the part that shows the Minangkabau characteristic. The section is then separated based on the Minangkabau decorative motifs. That motif was later processed and redesigned into batik motifs.

Therefore, as a result, the design motive is expected to be a characteristic of Minangkabau batik. Besides, the development of batik and its production are also expected to encourage the creative industry of the West Sumatra.

\section{RESULT AND DISCUSSION}

The illuminations motifs in the Minangkabau manuscript is not much different from the traditional Minangkabau decorations. However, there are differences as a form of the peculiarity of manuscript illumination. Illuminations of Minangkabau manuscripts can be grouped according to their shape and motif. The forms of Minangkabau manuscript illumination include the form of a frame and a double frame [18]. In line with that, Saktimulya [19] found frame illumination in the form of square, round, and variations.

Minangkabau manuscript illuminations in this frame-shaped are found in the Al Quran manuscripts. Meanwhile, the illumination of Minangkabau manuscripts can be grouped in plant motifs, animal motifs, sun and moon motifs, and other motifs.

In addition to showing the peculiarities of the origin of the manuscript, illumination has aesthetic and symbolic functions [18]. Aesthetic functions are related to the beauty of manuscripts, while symbolic functions relate to their relevance to the text. In line with this aesthetic function, illumination can be developed into decorative types. One form of development and utilization of illumination as decoration is the design of batik motifs.

This utilization is directly related to creative activities that are directly or indirectly related to industrial development, in this case, the culture-based creative industry. The creative industry is an activity that is based on the creativity, skill, and talents of individuals who have the potential for wealth and job creation and the use of intellectual devices [20].

According to Jerusalem [21], there are several aspects and stages that need to be done in developing creative industries, especially in fashion. The stage is the vision determination, the main objectives, catalyst determining, supporting aspects, and cluster determining. Vision determination needs to be achieved in relation to business development objectives. Catalysts are needed as supporting parties both material and nonmaterial. Supporting aspects include capital, human resources, and management. Clusters, in this case, are concentrated on the market, for example, the area and class of individual prospective customers. 
Most of the decorative motifs in Nusantara art are reflect our nation, but also come from foreign influences. This is common because cultural contact takes place naturally. For examples, phoenix, dragons, clouds, and rocks originating from China is found in many northern artworks in Java. Lotus flower which means birth originates from the tradition of Indian Hindu appear in temples or temple reliefs. Some decorative motifs are universal because they are also found in other countries, such as meander, tumpal, and swastika. With various decorative motifs, the quality of the art is actually better. This can be seen in the suitability of techniques, materials, colors, themes, shapes, and symbolic meanings. The ornamental archipelago can be found in batik motifs, woven, woven, pottery, wood carvings, and stone carvings.[22].

Batik is the drawing art on cloth. Initially, batik was only limited to the palace and the results for the clothes of the king and his family and followers. Because many of the followers of the king lived outside the palace, the batik art was brought by them out of the palace and worked in their respective places. After a long time, this batik art was imitated by the closest people and subsequently expanded to become the work of women in their households to fill their leisure time. Furthermore, batik, which was once the royal family's clothes, later became popular clothing for women, both men, and women[23], [24].

Compared to the motif of the illumination, batik motifs also have the characteristic of the region. Batik motifs that have been widely known include Solo and Yogyakarta with parang, Cirebon with mega mendung, and Pekalongan with pagi sore. In line with the development of batik motifs from the Minangkabau manuscript illumination, Hidayat [8]stated that the development of this typical Minangkabau batik motif could be one of the superior products of the West Sumatra creative industry. Minangkabau decorative motifs are one of the assets of West Sumatra that are feasible to be developed to be known more widely. Also, the creation of batik motifs from illumination is a form of creative evolution[25].

The tradition of batik in West Sumatra can be said to be old. Even so, if seen from the evidence, the history of the batik tradition in West Sumatra does not clear. At certain times the history of batik in West Sumatra arose but in the next period, it faded again. If noted, the history of batik in West Sumatra can at least be divided into 5 periods. The first period was during the kingdom of Dharmasraya (13th century AD), the second period during the kingdom of Pagaruyung (16 AD), the third period during the Dutch period (before independence), and the fourth period in the early days of Indonesian Independence, and the 5th, after Indonesian independence, at the end of the 20th century until now[26], [27].

Since its practice permitted individual creativity in the face of mass industrialization occurring in modernity, hand-made batik reflected the modernist credo to "bring art into life," a quality integral to its embrace by the Arts and Crafts movement. There was egalitarian endorsement from artisans, individual practitioners, and consumers, across geography, social milieu, and skill levels[28]. However, it cannot be denied that the development of batik in West Sumatra was influenced by batik from Java[29]which is seen in the development of Tanah Liek batik both from its motifs and techniques.

In the process, designing batik motifs proceeds through three steps, selection, designing, and coloring. At the selection step, consideration is given to manuscript illumination with striking patterns, motifs, and colors. At this step, the selected illumination motifs were sorted back so it is possible to create more than one motif. Then the design is carried out after the illumination part is to be modified. The final stage is coloring. 


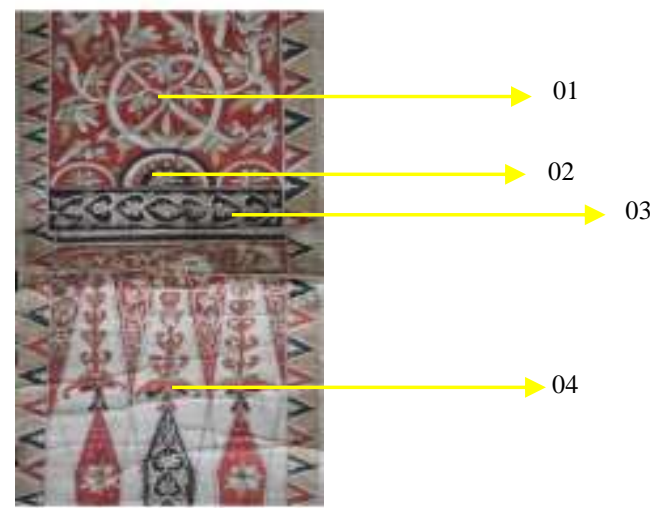

Figure 1. Illumination on Surau Mato Aie Manuscript

Designing batik motifs based on illumination requires the creator creativity. Very important to design and modify the illumination motif so that it can produce many variations of motifs. For example, the illumination of the manuscript in figure 1, obtained four patterns that could be further modified, namely $01,02,03$, and 04 (figure 1).

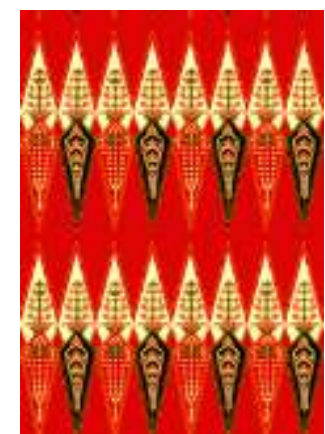

Figure 2. Design \#1

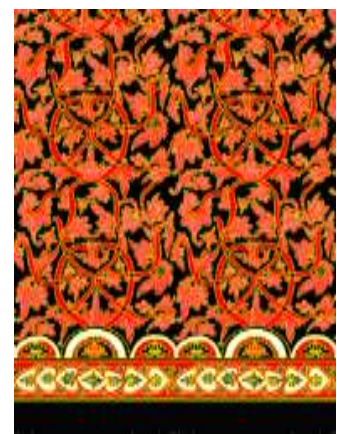

Figure 2. Design "Sulur Sirah"

That four patterns can be modified or combined so that they are expected to obtain more variants. From the chosen pattern, there are two design obtained (figures 2 and 3). Figure 2 is an example of a design that only uses one pattern from manuscript illumination. Meanwhile, figure 3 uses three patterns of selected manuscript illumination motifs. 


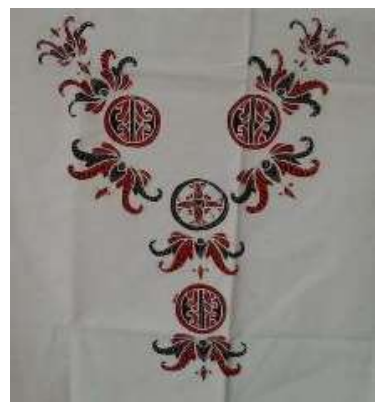

Figure 4.Design "SulurKoko"

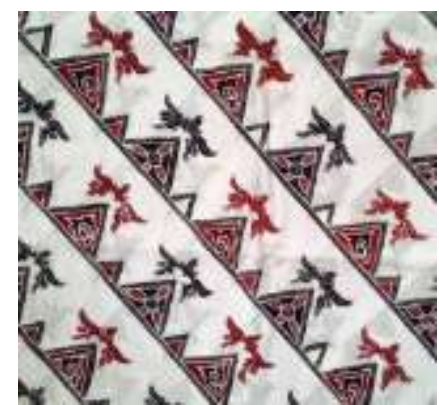

Figure 5.Design "Lereng Pucuak Rabuang"

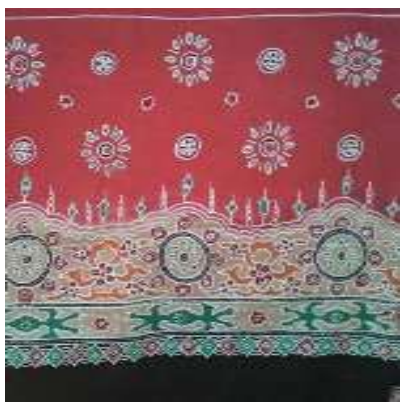

Figure 6.Design "Sirah Ustano"

The design of batik motifs was ultimately aimed at the production of batik cloth as a form of industry. In this case, the industry is a creative culture based on local culture [26]. The selection of manuscript illuminations found in surau which were later developed into batik motifs can be used as souvenirs for surau pilgrims [16]. The batik motif can also be used as a marker of certain surau in the West Sumatra region. This is in accordance with Zuriati's statement[18]that illumination is also a marker of the origin area of the manuscript.

\section{CONCLUSIONS}

Manuscript illumination can be defined as one of the cultural products of the past. It can be developed in the present context. Manuscript illumination can be recreated as batik motifs. The batik motif design from the Minangkabau manuscripts illumination is an attempt to develop philology both theoretically and practically. Theoretically, philology is the determinant field of fashion design development. Practically, it can develop culture-based creative industries. Its products can be used as an identifier other than as a method of developing creative industries.

\section{ACKNOWLEDGEMENTS}

The author expresses gratitude to Lembaga Penelitian dan Pengabdian kepada Masyarakat Universitas Andalas, Fakultas Ilmu Budaya Universitas Andalas, Program Studi Sastra Minangkabau Universitas Andalas, Masyarakat Pernaskahan Nusantara (MANASSA), and Asosiasi Dosen Pendidikan Bahasa Indonesia (ADOBSI).

\section{REFERENCES}

[1] B. Kurniawan, "Filologi Indonesia sebagai Metode dan Studi Sastra Melayu Klasik," in Penguatan Bahasa Indonesia di Dunia Internasional, 2013.

[2] M. Restall, "A History of the New Philology and the New Philology in History," Lat. Am. Res. Rev., vol. 38, no. 1, pp. 113-134, 2003.

[3] Mu'jizah, "Manuskrip Indonesia Sebagai Pustaka Dunia: Persebaran Dan Apresiasi," in Penguatan Bahasa Indonesia di Dunia Internasional, 2013.

[4] A. O. Safari, "Iluminasi dalam Naskah Cirebon," SUHUF J. Pengkaj. Al-Qur'an dan Budaya, vol. 3, no. 2, pp. 309-325, 2009.

[5] A. T. Gallop and B. Arps, Golden Letter: Writing Tradition of Indonesia. Jakarta: Lontar, 1991. 
[6] R. K. Luqman, K. L. Maulana, T. H. Retnowati, and H. Laente, "Learning Strategies of Ornamental Fine Arts with Manuscript Ilumination: Saintificial Correlation and Approach Study," in Proceedings of the International Conference on Art and Arts Education (ICAAE 2018), 2018.

[7] S. W. R. Mulyadi, "Kodikologi Melayu di Indonesia," Lembar Sastra Ed. Khusus, vol. 24, 1994.

[8] H. N. Hidayat, "Pengembangan Motif Ukiran Rumah Gadang Untuk Motif Kain: Revitalisasi dan Pengembangan Industri Kreatif," 2018.

[9] S. Sundusiah, Yulianeta, and Halimah, "Transformasi Sastra Klasik Menjadi Komik Sebagai Sarana Pendidikan Sastra Anak," in Konferensi Kesusastraan Internasional XX Himpunan Sarjana Kesusastraan Indonesia, 2009.

[10] Yulianeta, S. Sundusiah, and Halimah, "Revitalisasi Naskah Klasik Hikayat Raja Kerang ke dalam Film Animasi sebagai Media Pembelajaran Sastra di Era Digital," in Kongres Internasional dan Lokakarya Bahasa Daerah Maluku, 2017.

[11] Yulianeta, Halimah, S. Sundusiah, and Halimah, "Transformasi Hikayat Raja Kerang ke Dalam Komik Sastra Sebagai Bahan Ajar Pembelajaran Sastra Anak di Sekolah Dasar," in Naskah dan Relevansinya dalam Kehidupan Masa Kini, 2009.

[12] A. Syarief and Y. Sunarya, "The Semantics of 'New' Batik Clothes: Identifying Users 'Perception on the Colors and Patterns of Newly Developed West Javanese Batik Clothes," J. Vis. Art Des., vol. 1, no. 3, pp. 319-329, 2007.

[13] M. Rudiyanto, "Dari Iluminasi Naskah-Naskah Minangkabau ke Desain Motif Batik," in Naskah dan Relevansinya dalam Kehidupan Masa Kini, 2014.

[14] T. K. S. Dewi, "Ragam Hias dalam Naskah Kuno sebagai Alternatif Pengembangan Motif Batik Madura," in Naskah dan Relevansinya dalam Kehidupan Masa Kini, 2014.

[15] Nurhayati, "Kolaborasi Teknik Batik dengan Iluminasi Naskah Dewa Ruci Pura Mangkunegaran Surakarta," in Naskah dan Relevansinya dalam Kehidupan Masa Kini, 2014.

[16] Pramono, "Potensi Naskah-Naskah Islam Minangkabau untuk Industri Kreatif sebagai Pendukung Wisata Religi Ziarah di Sumatera Barat," IBDA J. Kaji. Islam dan Budaya, vol. 16, no. 2, pp. 328-349, Nov. 2018.

[17] R. Marah, Ragam Hias Minangkabau. Jakarta: Proyek Pengembangan Media Kebudayaan, Direktorat Jenderal Kebudayaan, Departemen Pendidikan dan Kebudayaan, 1987.

[18] Zuriati, "ILUMINASI NASKHAH-NASKHAH MINANGKABAU," J. Filol. Melayu, vol. 17, 2010.

[19] S. R. Saktimulya, "Memaknai Sěstradi melalui Iluminasi Naskah Koleksi Pura Pakualaman," in Simposium Internasional Pernaskahan Nusantara ke 14, 2012.

[20] J. Zheng and R. Chan, "The impact of 'creative industry clusters' on cultural and creative industry development in Shanghai," City, Cult. Soc., vol. 5, no. 1, pp. 9-22, Mar. 2014.

[21] M. A. Jerusalem, "Perancangan Industri Kreatif Bidang Fashion dengan Pendekatan Benchmarking pada Queensland's Creative Industry," in Seminar Nasional Program Studi Teknik Busana, 2009.

[22] A. Rahmatillah, "PENGERTIAN RAGAM HIAS." [Online]. Available: https://www.academia.edu/8615729/PENGERTIAN_RAGAM_HIAS. [Accessed: 29Aug-2015].

[23] I. Ulum, "Batik Dan Kontribusinya Terhadap Perekonomian Nasional," J. Bestari, no. 42, Apr. 2016. 
[24] A. Ekow and A. Vincentia, "Sirigu Symbols : A Metaphoric Element for Batik Prints," Arts Des. Stud., vol. 12, pp. 49-58, 2013.

[25] Y. Li, C.-J. Hu, and X. Yao, "Innovative Batik Design with an Interactive Evolutionary Art System," J. Comput. Sci. Technol., vol. 24, no. 6, pp. 1035-1047, 2009.

[26] Herwandi, Lindayanti, Sawirman, and Suryadi, "Industri Batik di Sumatera Barat (Perspektif Sejarah)," in Seminar Nasional Kearifan Lokal Nilai Adiluhung Batik Indonesia untuk Daya Saing Internasional, 2016.

[27] Djulianto Susantio, "Sejarah Batik," Majalah Arkeologi Indonesia, 2010. [Online]. Available: https://hurahura.wordpress.com/2010/11/14/sejarah-batik/.

[28] A. Lillethun, "Javanesque Effects : Appropriation of Batik and Its Transformations in Modern Textiles," in Textile Society of America Symposium Proceedings, 2004, pp. $34-43$.

[29] R. Legino and D. Forrest, "An Analysis of Javanese Influences on Malaysian Motifs in Batik Sarong Design," Int. J. Arts Soc., vol. 6, no. 4, pp. 215-225, 2011.

[30] K. Saddhono, S. T, Widodo, M. T. Al Makmun, and M. Tozu, "The study of philosophical meaning of batik and kimono motifs to foster collaborative creative industry." Asian Soc. Sci. vol. 10 no. 9 pp 52-61, 2014 